${ }^{\circledR}$ Entomologica Fennica. 27 August 1998

\title{
Host preference of Cisidae (Coleoptera) on tree-inhabiting fungi in northern Norway.
}

\author{
Tor-Erik Fossli \& Johan Andersen
}

Fossli, T.-E. \& Andersen, J. 1998: Host preference of Cisidae (Coleoptera) on tree-inhabiting fungi in northern Norway. - Entomol. Fennica 9: 65-78.

Fruiting bodies of tree-inhabiting "macrofungi" (Polyporaceae, Hymenochaetaceae, Corticiaceae and Tremellaceae) were collected in 1993-1996 in Troms county, northern Norway for investigation of host specificity of Cisidae species. Three methods of estimating the amount of fruiting bodies were compared: 1) dry weight, 2) calculation of volume and 3) measure of volume. They were all highly correlated $(R=0.79-0.96)$, but only method 1$)$ and 3 ) were applicable irrespective of shape and therefore used in the statistical analyses concerning host preferences. 31 different species and more than 1000 units of tree-living fungi were investigated and yielded about 15500 individuals and 13 species of Cisidae. The cisid species showed preference for one single genus or species of fungi. Cis boleti, Cis hispidus and Octotemnus glabriculus preferred Trametes spp., Cis comptus preferred Cerrena unicolor, Cis lineatocribratus and Cis jacquemarti preferred Fomes fomentarius, while Cis punctulatus preferred Trichaptum spp. Orthocis festivus and Ropalodontus strandi appeared to be even more specific, with occurrence exclusively in Stereum rugosum and Fomes fomentarius, respectively. Cis bidentatus showed no specific host selection (polyphagous). A spatial segregation of the cisids $R$. strandi, $C$. jacquemarti and C. lineatocribratus was evident regarding height above ground of the fungus $F$. fomentarius. Microclimatic factors cannot explain the host selection of the species, but Sulcacis affinis, Sulcacis fronticornis and Ennearthron cornutum were exclusively found in fungi in warm and dry positions.

Tor-Erik Fossli \& Johan Andersen, Institute of Biology, Dept. of Ecology/ Zoology, University of Troms $\phi, N-9037$ Troms $\phi$, Norway.

Received 27 March 1997, accepted 2 April 1998

\section{Introduction}

Fungivorous insects are faced with a variable resource. Thus, the quality and durability of the resource varies with species and the stage of sporophore development. Furthermore, the temporal and spatial occurrence of the resource is often variable. The spatial distribution of fruiting bod- ies in many species of fungus is markedly aggregated, with the sporophores growing in tight clusters, while in others the sporophores occur singly and more or less randomly.

There seems to be a varying degree of host specificity among insect species inhabiting Basidiomycetes. Insect species adapted to fungi with short-living fruiting bodies, e.g. most fungi spe- 


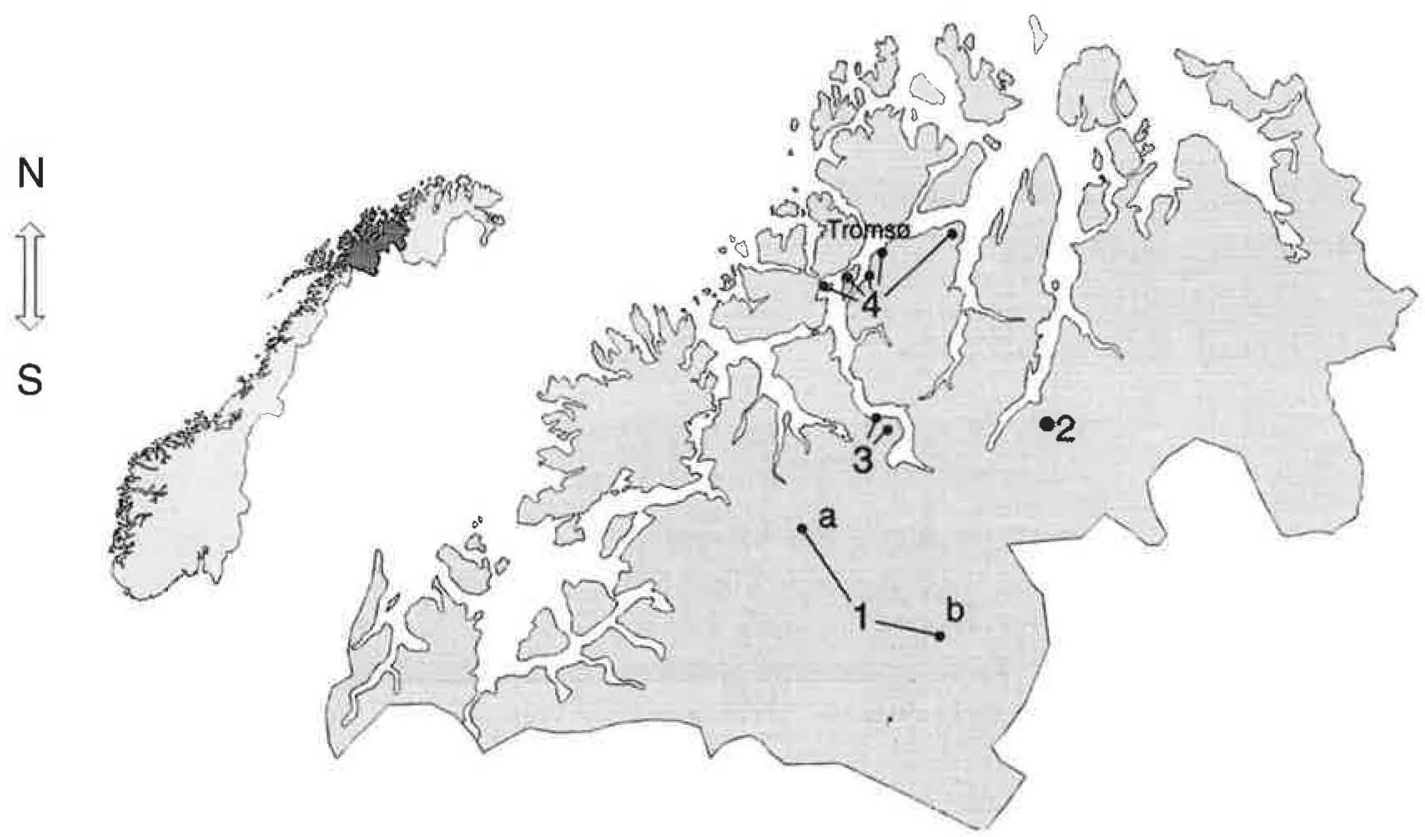

Fig. 1. Map showing the location of the four fields: 1: Målselvdalen and Dividalen; 2: Skibotn; 3: Balsfjord; 4: Tromsø.

cies occurring on the forest floor, generally show weak host specificity (Crowson 1981, Jonsell \& Nordlander 1995). On the contrary, the large number of insect species adapted to tree-living fungi (Gilbertson 1984) may be more specialized (Jonsell \& Nordlander 1995). The tenebrionid beetle Bolitophagus reticulatus (L.) for example, has the polypore Fomes fomentarius (L.: Fr.) Kickx as the main host (Krasutskiy 1996, Midtgaard 1996). Several studies of the species of the family Cisidae, which seem to be well adapted to tree-living fungi, indicate that they may be quite host specific (Saalas 1923, Benick 1952, Graves 1960, Paviour-Smith 1960a, Matthewman \& Pielou 1971, Lawrence 1971, 1973, Ackerman \& Shenefeldt 1973, Kaila et al. 1994, Thunes 1994, Jonsell \& Nordlander 1995 , Økland 1995, Krasutskiy 1996).

However, common for all the studies done so far on host preference of the family Cisidae and other tree-fungus living insects, is the lack of a quantitative measure of the host sample size. The total number of investigated fruiting bodies alone gives no information of quantity (volume, weight) examined. Intuitively this is assumed to be important when the purpose is to find out to what extent species show preferences to certain fungi. There- fore, in the present study, we have aimed at making quantitative measurements for each fungus unit.

The purpose of this study is: 1) to find a useful way of measuring the volume of fruiting bodies, thereby comparing methods of estimating volume to find a valid/useful measure of size to rank order, 2) examine if the species of the family Cisidae established in northern Norway show host preference, 3) examine whether height above ground of sporocarps (only for $F$. fomentarius) and microclimatic factors affect the spatial distribution of the species.

The present study is limited to tree-living "macrofungi" species.

\section{Study area and the taxa of fungi}

Four main sites (field 1-4), located in Troms county, northern Norway, were investigated (Fig. 1). They include inland, fjord as well as coastal districts: field 1, Målselvdalen and Dividalen (site 1a and $1 \mathrm{~b}$ ); field 2, Skibotndalen; field 3, Balsfjord (site $3 \mathrm{a}$ and $3 \mathrm{~b}$ ); field 4, Troms $\varnothing$.

Site 1a was searched both at the bottom and on the hill-side of the valley, facing south or south- 
west, except one sampling site in Målselvdalen where the slope was facing north. The selected area contained mainly Scots pine (Pinus sylvestris L.), and birch (Betula pubescens Ehrh.), but there were also some willows (Salix spp.), aspen (Populus tremula $\mathrm{L}$.) and alder (Alnus incana L.). The forest in the investigated area was old with a few clearcuts and had a high density of dead wood.

Field 2 was on the hillside of the valley, either facing southwest or in flat terrain. In this field $P$. sylvestris was dominating, but $B$. pubescens was also present.

In field 3 , site a, investigations were done either on a north-facing or in a weakly southwestfacing position. B. pubescens was the dominating tree species in most of the area.

In field 4, five different sites were examined: Tromsøya, where the examined area had a weakly northwest facing or flat position; Håkøybotn at Kvaløya, where the slope was facing east; Tønsvikdalen, where the investigation was done in almost flat terrain along the river, but also in a steep southwest facing slope; Oldervikdalen, where the investigated area had a steep south-east facing position; and Tromsdalen, where the slope was facing southwest or northwest. In all these sites samples were also taken from flat terrain. All the sites in field 4 contain deciduous forests, dominated by $B$. pubescens. A. incana and Salix spp. predominated along brooks and rivers in all the four fields. Within each of the fields 1 and 3 an area of a given size was selected (termed $1 b$ and $3 b$ ). Site $1 b$ was situated in an old forest of mainly $P$. sylvestris and $B$. pubescens, on a slope facing southwest. Site $3 b$ was partly situated in old wood predominated by $B$. pubescens and $A$. incana, partly in a clearcut with many stumps and twigs. The terrain is flat or weakly southwest-facing.

A summary and a brief description of the fungi taxa sampled are given in Table 1. The taxonomy follows Ryvarden (1991). Identifications are based on keys and descriptions in Ryvarden (1976, 1978), Eriksson et al. (1984) and Ryvarden and Gilbertson (1993).

\section{Material and methods}

The field investigation was carried out from the middle of July to late November 1993, and from early April to late October in 1994-1996. Sporocarps were cut at their base and brought to the laboratory. Usually not all the fungus material of an unit (trunk, twig or stump) was removed. For species with very small sporocarps, e.g. Trichaptum spp., bark infected with mycelium was also collected. No division of successional stages of fungi for the material collected in 1993-1994 was done to avoid loss of cisid species due to succession, as Paviour-Smith (1960b) and Klimaszewski and Peck (1986) showed for Piptoporus betulinus and Polyporus squamosus, respectively. However, our results from 1993-1994 indicated that only dead parts of the fruiting bodies of woody hard species were usually attacked by cisids, whereas the species with soft sporocarps may be attacked when still alive (see also Graves 1960, Ackerman \& Shenefeldt 1973). Consequently, alive and uninfected sporocarps were not sampled in site 1b in 1994 and in field 3b in 1995-1996. Therefore the sporocarps sampled in site $1 \mathrm{~b}$ and $3 \mathrm{~b}$ are in a more comparable stage than the rest of the material.

For the 1994-1996 samples, height above ground, exposure (exposed/shady), ground moisture (dry/humid) and topography (slope/flat terrain) parameters were noted for each sample.

The sampling in site $1 \mathrm{~b}$ was performed from 12 to 23 September 1994, in 3b 19-20 September and 4-5 October 1995. Dead and/or attacked sporocarps from all units infected with fungi were collected. In field $1 \mathrm{~b}$, however, only $50 \%$ of the sporocarps of Phellinus spp. and Fomes fomentarius were sampled.

Different methods were used to extract the beetles depending on fungus species. Fungi with soft tissue were picked to pieces and all beetles were collected. Some samples were laid on a grate on top of a collecting jar and placed under a 60 -W table lamp to force the inhabitants out of the fungus. Emerging insects were sampled once a day, but when the number of emerging individuals declined to zero, the fungi were investigated to insure that all adult specimens were taken.

Because of the woody or leathery fruiting bodies of $F$. fomentarius, $P$. betulinus and Phellinus spp., these fungi were placed in plastic funnels standing in glass jars, and the emerging insects were picked once a week until the number of specimen declined to zero.

All samples were stored for eclosion and investigated three times during the winter. Thus, all the specimens that were eggs, larvae, pupae or beetles when the fungi were collected, were sampled. In addition, a new generation of beetles was sampled. Since the fruiting bodies of $F$. fomentarius, and Phellinus spp. were not picked to pieces, there is a possibility that individuals of cisidae may have remained inside the hosts and hence that their abundance was underestimated in these fungi species. Cisids were identified by means of keys and descriptions in Hansen (1951), Freude et al. (1967) and Fjellberg (1985) and preserved in 70\% ethanol. The nomenclature follows Lundberg (1995).

The dry weights of all the fungi collected in 1994-1996 were recorded after one week at room temperature (R.H. = 17-20\%). For the fungi collected in 1994, the volume of $F$. fomentarius, $P$. betulinus and the genus Phellinus was calculated by measuring maximum length (distance from 
Table 1. Description of the tree-living fungi species sampled in 1993-96. Equal numbers (given behind genus) indicate a close relationship between the respective genera. Different numbers $(1,2,3,5,6$ and 9$)$ indicate that the genera are separated in distinct groups of the family Polyporaceae (Ryvarden 1991). a and $p$ denotes annual and perennial, respectively.

\begin{tabular}{|c|c|c|c|c|c|c|}
\hline $\begin{array}{l}\text { Family } \\
\text { Genus }\end{array}$ & Species & $\begin{array}{l}\text { Life } \\
\text { cycle }\end{array}$ & $\begin{array}{l}\text { Fruiting } \\
\text { body }\end{array}$ & $\begin{array}{l}\text { Host } \\
\text { trees }\end{array}$ & $\begin{array}{l}\text { Distribution } \\
\text { in Troms }\end{array}$ & $\begin{array}{l}\text { Hyphal } \\
\text { system }\end{array}$ \\
\hline \multicolumn{7}{|l|}{ Polyporaceae } \\
\hline \multirow[t]{3}{*}{$\begin{array}{l}\text { Polyporus (1) } \\
\text { s. str Fr. }\end{array}$} & melanopus Fr. & a & $\begin{array}{l}\text { soft when } \\
\text { fresh }\end{array}$ & $\begin{array}{l}\text { dead } \\
\text { deciduous } \\
\text { wood }\end{array}$ & $\begin{array}{l}\text { scattered, } \\
\text { but } \\
\text { not rare }\end{array}$ & dimitic \\
\hline & squamosus Fr. & a & $\begin{array}{l}\text { fleshy when } \\
\text { fresh }\end{array}$ & $\begin{array}{c}\text { living or } \\
\text { dead deciduous } \\
\text { trees }\end{array}$ & not common & dimitic \\
\hline & varius $\mathrm{Fr}$. & a & $\begin{array}{l}\text { tough when } \\
\text { fresh }\end{array}$ & $\begin{array}{l}\text { living or } \\
\text { dead deciduous } \\
\text { trees }\end{array}$ & common & dimitic \\
\hline $\begin{array}{l}\text { Pleurotus (1) } \\
\text { (Fr.) Kumm. }\end{array}$ & $\begin{array}{l}\text { pulmonarius } \\
\text { (Fr.) Quel }\end{array}$ & a & soft & $\begin{array}{c}\text { deciduous } \\
\text { Betula }\end{array}$ & common & dimitic \\
\hline \multirow[t]{3}{*}{$\begin{array}{l}\text { Trametes (2) } \\
\text { Fr. }\end{array}$} & $\begin{array}{l}\text { hirsuta } \\
\text { (Fr.) Pilát }\end{array}$ & a & soft & deciduous & common & trimitic \\
\hline & $\begin{array}{l}\text { pubescenc } \\
\text { (Fr.) Pil }\end{array}$ & a & soft & deciduous & rather rare & trimitic \\
\hline & $\begin{array}{l}\text { ochracea } \\
\text { (Fr.) Pil. }\end{array}$ & a & soft & deciduous & common & trimitic \\
\hline $\begin{array}{l}\text { Pycnoporus (2) } \\
\text { Karst. }\end{array}$ & $\begin{array}{c}\text { cinnabarinus } \\
\text { (Jacq.: Fr.) Karst. }\end{array}$ & a & $\begin{array}{l}\text { tough and } \\
\text { fibrous }\end{array}$ & $\begin{array}{l}\text { deciduous } \\
\text { wood }\end{array}$ & $\begin{array}{c}\text { scattered, } \\
\text { not common }\end{array}$ & trimitic \\
\hline $\begin{array}{l}\text { Cerrena (2) } \\
\text { S. F. Gray }\end{array}$ & $\begin{array}{l}\text { unicolor } \\
\text { (Fr.) Murr. }\end{array}$ & $p$ & $\begin{array}{l}\text { tough to } \\
\text { corky }\end{array}$ & $\begin{array}{l}\text { deciduous, } \\
\text { mostly Betula }\end{array}$ & $\begin{array}{c}\text { common, } \\
\text { follows Betula }\end{array}$ & trimitic \\
\hline \multirow[t]{3}{*}{$\begin{array}{l}\text { Trichaptum (2) } \\
\text { Murr. }\end{array}$} & $\begin{array}{l}\text { abietinus } \\
\text { (Fr.) Ryv. }\end{array}$ & a & $\begin{array}{l}\text { soft when } \\
\text { fresh }\end{array}$ & $\begin{array}{l}\text { coniferous } \\
\text { wood }\end{array}$ & $\begin{array}{l}\text { scattered, } \\
\text { not common }\end{array}$ & dimitic \\
\hline & $\begin{array}{l}\text { fusco-violaceus } \\
\text { (Ehrenberg) } \\
\text { Donk.: Fr. Ryv. }\end{array}$ & a & $\begin{array}{l}\text { soft when } \\
\text { fresh }\end{array}$ & $\begin{array}{l}\text { coniferous } \\
\text { wood }\end{array}$ & common & dimitic \\
\hline & $\begin{array}{c}\text { laricinus } \\
\text { (Karst.) Ryv. }\end{array}$ & $p$ & $\begin{array}{l}\text { soft when } \\
\text { fresh }\end{array}$ & $\begin{array}{l}\text { coniferous } \\
\text { wood }\end{array}$ & rare & dimitic \\
\hline $\begin{array}{l}\text { Gloeophyllum (3) } \\
\text { Karst. }\end{array}$ & $\begin{array}{l}\text { sepiarium } \\
\text { (Fr.) Karst. }\end{array}$ & $a-p$ & $\begin{array}{l}\text { tough and } \\
\text { flexible }\end{array}$ & $\begin{array}{l}\text { both coniferous } \\
\text { and deciduous } \\
\text { woods, but most } \\
\text { frequent on } \\
\text { the former }\end{array}$ & $\begin{array}{l}\text { scattered, } \\
\text { not common }\end{array}$ & trimitic \\
\hline $\begin{array}{l}\text { Piptoporus (3) } \\
\text { Karst. }\end{array}$ & $\begin{array}{l}\text { betulinus } \\
\text { (Fr.) Karst. }\end{array}$ & a & $\begin{array}{l}\text { elastic when } \\
\text { fresh }\end{array}$ & $\begin{array}{c}\text { weakened or } \\
\text { dead Betula }\end{array}$ & common & di(tri)mitic \\
\hline $\begin{array}{l}\text { Fomitopsis (3) } \\
\text { Karst. }\end{array}$ & $\begin{array}{c}\text { pinicola } \\
\text { (Fr.) Karst. }\end{array}$ & $\mathrm{p}$ & $\begin{array}{c}\text { corky to } \\
\text { woody hard }\end{array}$ & $\begin{array}{l}\text { common on } \\
\text { Picea }\end{array}$ & rather rare & trimitic \\
\hline
\end{tabular}


Table 1. Continued.

\begin{tabular}{|c|c|c|c|c|c|c|}
\hline $\begin{array}{l}\text { Family } \\
\text { Genus }\end{array}$ & Species & $\begin{array}{l}\text { Life } \\
\text { cycle }\end{array}$ & $\begin{array}{l}\text { Fruiting } \\
\text { body }\end{array}$ & $\begin{array}{l}\text { Host } \\
\text { trees }\end{array}$ & $\begin{array}{l}\text { Distribution } \\
\text { in Troms }\end{array}$ & $\begin{array}{l}\text { Hyphal } \\
\text { system }\end{array}$ \\
\hline $\begin{array}{l}\text { Oxyporus (5) } \\
\text { Donk }\end{array}$ & $\begin{array}{c}\text { populinus } \\
\text { (Bourdot \& } \\
\text { Galzin) Donk }\end{array}$ & a & $\begin{array}{l}\text { soft when } \\
\text { young, hard } \\
\text { when dry }\end{array}$ & $\begin{array}{l}\text { deciduous } \\
\text { trees }\end{array}$ & $\begin{array}{l}\text { rather } \\
\text { rare }\end{array}$ & monomitic \\
\hline $\begin{array}{l}\text { Hapalopilus (6) } \\
\text { Karst. }\end{array}$ & $\begin{array}{c}\text { nidulans } \\
\text { (Fr.) Karst. }\end{array}$ & a & $\begin{array}{c}\text { soft and } \\
\text { watery when } \\
\text { fresh }\end{array}$ & $\begin{array}{c}\text { dead } \\
\text { deciduous } \\
\text { wood }\end{array}$ & $\begin{array}{l}\text { rather } \\
\text { rare }\end{array}$ & monomitic \\
\hline $\begin{array}{l}\text { Bjerkandera (6) } \\
\text { Karst. }\end{array}$ & $\begin{array}{c}\text { adusta } \\
\text { (Willd.: Fr.) } \\
\text { Karst. }\end{array}$ & a & $\begin{array}{c}\text { soft and } \\
\text { pliable } \\
\text { when fresh }\end{array}$ & $\begin{array}{l}\text { dead } \\
\text { deciduous } \\
\text { wood }\end{array}$ & $\begin{array}{l}\text { rather } \\
\text { rare }\end{array}$ & monomitic \\
\hline $\begin{array}{l}\text { Fomes (9) } \\
\text { (Fr.) Fr. }\end{array}$ & $\begin{array}{l}\text { fomentarius } \\
\text { (L.: Fr.) Kickx }\end{array}$ & $p$ & woody hard & deciduous & $\begin{array}{c}\text { very } \\
\text { common }\end{array}$ & trimitic \\
\hline
\end{tabular}

Hymenochaetaceae

\begin{tabular}{|c|c|c|c|c|c|c|}
\hline \multirow[t]{3}{*}{$\begin{array}{l}\text { Phellinus } \\
\text { Quél. }\end{array}$} & $\begin{array}{l}\text { igniarius } \\
\text { (Fr.) Quél. }\end{array}$ & $p$ & woody hard & deciduous & common & dimitic \\
\hline & $\begin{array}{l}\text { lundellii } \\
\text { Niemelä }\end{array}$ & $\mathrm{p}$ & woody hard & $\begin{array}{l}\text { dead } \\
\text { deciduous } \\
\text { wood }\end{array}$ & common & dimitic \\
\hline & $\begin{array}{l}\text { nigricans } \\
\text { (Fr.) Karst. }\end{array}$ & $p$ & woody hard & deciduous & $\begin{array}{c}\text { scattered, } \\
\text { not rare }\end{array}$ & dimitic \\
\hline $\begin{array}{l}\text { Inonotus } \\
\text { Karst. }\end{array}$ & $\begin{array}{l}\text { obliquus } \\
\text { (Fr.) Pilat }\end{array}$ & a & $\begin{array}{l}\text { soft when } \\
\text { fresh }\end{array}$ & $\begin{array}{l}\text { deciduous } \\
\text { wood }\end{array}$ & common & monomitic \\
\hline
\end{tabular}

\section{Corticiaceae}

\section{Stereum \\ Pers.}

rugosum
(Pers.: Fr.) Fr.
sanguinolentum
(Alb. \& Schw.:Fr.)
Fr.
subtomentosum
Po.
hirsutum
(Willd.: Fr.)
S. F. Gray

Plicatura

Karst.

Chondrostereum

Po.
nivea
(Sommerf.: $\mathrm{Fr}$.)
Karst.

\section{Tremellaceae}

Exidia $\mathrm{Fr}$.

Tremélla Fr.

purpureum
(Pers.: Fr.) Po. a

tough

tough when when dry

a tough when fresh, hard when dry

deciduous, Alnus spp.

deciduous

fresh, when dry

coniferous wood

$\begin{array}{ccc}\text { deciduous } & \text { common monomitic } \\ \begin{array}{c}\text { coniferous } \\ \text { wood }\end{array} & \text { common monomitic } \\ & \\ \text { deciduous, } & \begin{array}{c}\text { rather } \\ \text { rare }\end{array} & \\ \text { Alnus spp. } & \text { ranomitic }\end{array}$

common monomitic

deciduous wood

deciduous Betula

scattered, monomitic not rare 
trunk outwards when the sporophores were viewed on the tree), width (from side to side) and height (from apex to lower surface) by using a ruler. "Apex" is used according to the description by Matthewman \& Pielou (1971).

To get an exact measure of volume, each sample from site $1 \mathrm{~b}$ and $3 \mathrm{~b}$, was placed in a thin plastic bag. The air was removed by a vacuum pump. Then each vacuumpacked fungus was dipped into a jar completely filled with water, which was placed into another collecting jar where the surplus water was collected. This surplus water was measured, giving the volume of each sample. This method is termed "measure of volume".

Correlations between weight and volume (calculated and measured) were tested for data sampled in field $1 b$, using Spearman Rank Order Correlations.

The frequency of each cisid species in the fungi deviated significantly from a normal distribution ( $\mathrm{d}$ between 0.3892 and $0.5235, \mathrm{p}<0.01$, Kolmogorov-Smimov one sample tests). Kruskal-Wallis tests were therefore used in the statistical analysis. When this test gave significant differ- ences between groups, Mann-Whitney U tests (with corrections for tied variables, vide Sokal \& Rohlf (1981)), were used in the further statistical analyses.

The six data sets (Table 2-7) were treated separately when testing for host preference, using individuals per gram fungi (Table 2-5) or individuals pr. ml fungi (Table 6 and 7). For each cisid species, the fungus taxon with the highest number of individuals was tested for difference in density against all others. Taxa of fungi inhabited by less than ten individuals of a particular species, or taxa with less than four attacks, were not included. We did not control significance levels for multiple comparisons, because this significantly increases the probability of dismissing real patterns (Rothman 1990).

In $F$. fomentarius, the effect of height above ground on density of beetles (individuals per gram) was tested with Mann-Whitney U tests for three beetle species, and Chisquare tests were used to test pairwise differences in prevalence between the species.

The following classification was used to elucidate the

Table 2. Mean number of cisids pr. 10 gram fungi found in fruiting bodies of Trametes spp., Fomes fomentarius, Phellinus spp., Piptoporus betulinus, Cerrena unicolor, Stereum sanguinolentum and Trichaptum spp. sampled in Dividalen and Målselvdalen. Total number of cisids is given in brackets while the number of fungi in which they were found is given by the following number. Sampled fungi without attack and $N \leq 7$ are not considered in the table: Gloeophyllum sepiarium $(\mathrm{N}=7)$, Polyporus spp. $(\mathrm{N}=6)$, Fomitopsis pinicola $(\mathrm{N}=3)$, Stereum spp. $(\mathrm{N}=2)$, Oxyporus populinus $(\mathrm{N}=2)$, Exidia spp. $(\mathrm{N}=2)$ and Plicatura nivea $(\mathrm{N}=1)$. Host preference for fungi species was tested with Mann-Whitney $U$ Test for all cisid species pr. gram fungi exceeding ten individuals in at least one fungus species. Figures with asterics denote that the abundance is significantly higher than in all the other fungus species $(p<0.05)$.

\begin{tabular}{lccccccc}
\hline Fungi name: & Tram. & F. fom. & Phell. & P. bet. & C. unic. & S. sang. & Tric. \\
$\mathrm{N}:$ & 52 & 92 & 76 & 43 & 22 & 21 & 32 \\
$\mathrm{n}:$ & 48 & 52 & 6 & 15 & 11 & 3 & 27 \\
Fungi group: & $(2)$ & $(9)$ & & $(3)$ & (2) & (2) \\
\hline
\end{tabular}

Cisidae

\begin{tabular}{|c|c|c|c|c|c|c|c|}
\hline Cis bidentatus & $0.02(2) 1$ & $0.21(54) 9$ & $0.02(2) 1$ & $\star 2.48(151) 12$ & $0.13(9) 3$ & $0.06(1) 1$ & 0 \\
\hline Cis jacquemarti & 0 & * $3.04(785) 41$ & $0.03(4) 4$ & $1.18(72) 6$ & $0.09(6) 1$ & 0 & 0 \\
\hline Cis lineatocribratus & 0 & * $0.28(73) 12$ & $0.22(30) 2$ & $0.03(2) 2$ & $0.01(1) 1$ & $0.11(2) 1$ & 0 \\
\hline Cis comptus & $0.51(46) 5$ & 0 & 0 & 0 & * $6.16(420) 9$ & $0.06(1) 1$ & $0.01(2) 1$ \\
\hline Cis boleti & * $12.13(1100) 33$ & 0 & 0 & 0 & 0 & 0 & 0 \\
\hline Cis hispidus & * $11.49(1042) 30$ & $<0.01(1) 1$ & 0 & 0 & 0 & 0 & 0 \\
\hline Cis punctulatus & 0 & 0 & 0 & 0 & 0 & 0 & * $0.84(113) 27$ \\
\hline Octotemnus glabriculus & * $3.34(303) 21$ & 0 & 0 & 0 & 0 & 0 & 0 \\
\hline Sulcacis fronticornis & $3.57(324) 2$ & 0 & 0 & 0 & 0 & 0 & 0 \\
\hline Sulcacis affinis & 0.20 (1) 1 & 0 & 0 & 0 & 0 & 0 & 0 \\
\hline Ennearthron cornutum & 0 & $0.04(11) 1$ & 0 & 0 & 0 & 0 & 0 \\
\hline Ropalodontus strandi & 0 & * $3.25(841) 14$ & 0 & 0 & 0 & 0 & 0 \\
\hline Number of species & 7 & 6 & 3 & 3 & 4 & 3 & 2 \\
\hline Volume (cal.)• & - & 18579 & 8276 & 4500 & - & - & - \\
\hline Weight (g.) & 907 & 2582 & 1342 & 610 & 682 & 175 & $\ll 1352$ \\
\hline
\end{tabular}

$\mathrm{N}$ : total number of fungi sampled, $\mathrm{n}$ : number of attacked fungi, $\bullet$ : volume calculated $\left(\mathrm{cm}^{3}\right)$.

Note Table 2-7: For large species of fungi (e.g. Fomes fomentarius, Phellinus spp., Piptoporus betulinus) N denotes one sporocarp, while for small species of fungi (e.g. Trametes spp., Cerenna unicolor, Stereum spp., Trichaptum spp.) it denotes number of units (tree, trunk, stump or twig). 
host selection of the cisid species:

1. Optimal host, where the individuals feed and reproduce, and the highest density of each species is found.

2. Suboptimal host, where the species feed and may reproduce, but have a lower density and prevalence than in 1).

3. Fungi where only stragglers are found, e.g. occasionally in fungi of the "wrong" species. The term "straggler" is used in cases where the total number of individuals found in each fungus species is less than ten, and when less than four fungi units were found attacked. No sign of reproduction is evident, but the individuals may feed.

4. Fungi where no individuals were found

\section{Results}

There was a highly significant $(\mathrm{p}<0.005)$ and positive correlation $(R \geq 0.79)$ between weight and volume, both with regard to each fungus and all fungi combined, and whether volume was measured or calculated. This gives the opportunity to use one of three methods: 1) dry weight; 2) calculation of volume; or 3 ) measure of volume.

In total, four fungi families, 20 genera and 31 fungi species were found and investigated. The family Polyporaceae is divided into 12 groups (Ryvarden 1991, Table 1). Fungi from six of these groups were examined. (1) The Polyporus group: Polyporus and Pleurotus; (2) the Trametes group: Trametes, Pycnoporus, Cerrena and Trichaptum; (3) the Daedalea group: Gloeophyllum, Piptoporus and Fomitopsis; (5) the Rigidoporus group: $O x y$ porus; (6) the Tyromyces group: Bjerkandera and Hapalopilus, and (9) the Fomes group: Fomes.

Totally, 13 cisid species of the 29 recorded from Norway (Lundberg 1995), were found in nine taxa of fungi.

A significant difference in density was evident for all cisid species tested statistically across taxa of fungi (Table 2-7). Most of the cisid species showed a similar host occurrence regardless of geographical location, although the composition of cisid and polypore species varied.

Cis boleti (Scopoli), Cis hispidus Payk. and Octotemnus glabriculus (Gyll.) were most abundant in Trametes spp., whereas Cis comptus Gyll. was most common in Cerrena unicolor. Cis punctulatus Gyll. occurred exclusively in Trichaptum spp. Cis jacquemarti Mell. and Cis lineatocribratus Mell.

Table 3. Mean number of cisids pr. 10 gram fungi found in fruiting bodies of Trametes spp., Phellinus spp., Cerrena unicolor, Stereum sanguinolentum, Trichaptum spp., Piptoporus betulinus, Stereum hirsutum and Pleurotus pulmonarius sampled in Skibotndalen. Total number of cisids is given in brackets while the number of fungi in which they were found is given by the following number. Sampled fungi not considered in the table: Fomes fomentarius $(\mathrm{N}=1)$, Gloeophyllum sepiarium $(\mathrm{N}=2)$, Exidia spp. $(\mathrm{N}=2)$ and Hapalopilus nidulans $(\mathrm{N}=1)$. For further explanation see Table 2.

\begin{tabular}{lcccccccc}
\hline Fungi name: & Tram. & Phell. & C. unic. & S. sang. & Tric. & P. bet. & S. hirs & Pleur. \\
$\mathrm{N}:$ & 19 & 11 & 3 & 15 & 23 & 10 & 2 & 5 \\
$\mathrm{n}:$ & 17 & 1 & 2 & 1 & 14 & 0 & 1 & 1 \\
Fungi group: & $(2)$ & & $(2)$ & & $(2)$ & $(3)$ & & $(1)$
\end{tabular}

\begin{tabular}{lcc}
\hline Cisidae & & \\
Cis bidentatus & 0 & $0.11(3) 1$ \\
Cis punctulatus & 0 & 0 \\
Cis comptus & $0.32(18) 3$ & 0 \\
Cis boleti & $\star 13.53(748) 16$ & 0 \\
Cis hispidus & $\star 13.65(755) 11$ & 0 \\
Orthocis festivus & 0 & 0 \\
Octotemnus glabriculus & $0.33(18) 2$ & 0 \\
Sulcacis affinis & $0.29(16) 3$ & 0 \\
Number of species & 5 & 1 \\
Volume (cal.) & - & 1643 \\
Weight (g.) & 553 & 280
\end{tabular}

$\begin{array}{cc}0 & 0.70(3) 1 \\ 0 & 0 \\ 0.70(4) 1 & 0 \\ 6.50(37) 1 & 0 \\ 1.23(7) 1 & 0 \\ 0 & 0 \\ 1.05(6) 1 & 0 \\ 0 & 0 \\ 4 & 1 \\ - & - \\ 57 & 43\end{array}$

$\begin{array}{cc}0.11(3) 2 & 0 \\ \star 2.86(75) 14 & 0 \\ 0.11(3) 1 & 0 \\ 0 & 0 \\ 0 & 0 \\ 0 & 0 \\ 0 & 0 \\ 0 & 0 \\ 3 & 0 \\ - & 1371 \\ <262 & 342\end{array}$

$\begin{array}{cc}0.53(2) 1 & 0 \\ 0 & 0 \\ 0 & 0 \\ 0 & 0.10(1) 1 \\ 0 & 0.10(1) 1 \\ 0.26(1) 1 & 0 \\ 0 & 0 \\ 0 & 0 \\ 2 & 2 \\ - & - \\ 38 & 94\end{array}$

$\mathrm{N}$ : total number of fungi sampled. For further explanation see Table 2. n: number of attacked fungi, $\bullet$ : volume calculated $\left(\mathrm{cm}^{3}\right)$. 
were most abundant in Fomes fomentarius. Ropalodontus strandi Lohse was exclusively found in F. fomentarius whereas Orthocis festivus (Panzer) almost exclusively occurred in Stereum rugosum. Cis bidentatus (Olivier) occurred in eight taxa, but it was most common in $F$. fomentarius, $C$. unicolor, $P$. betulinus and $S$. rugosum.

Sulcacis affinis (Gyll.), Sulcacis fronticornis (Panzer) and Ennearthron cornutum (Gyll.) were not tested statistically for host preferences due to the criteria mentioned in section 3 . However, E. cornutum was exclusively found in $F$. fomentarius. Although low-numbered, the find of two dead adult specimens in one sporocarp, might indicate breeding and reproduction. The present results for $S$. affinis and $S$. fronticornis indicate that these species might be host specific, due to their occurrence exclusively in Trametes spp.

Trametes spp. were commonly infected with C. boleti, $C$. hispidus and $O$. glabriculus regardless of whether the fungi occurred in shady and moist, or exposed and dry positions. The same was true for $R$. strandi, $C$. jacquemarti and $C$. lineatocribratus in $F$. fomentarius, for $C$. comptus in C. unicolor and for C. punctulatus in Trichaptum spp. However, the spatial distribution of $S$. fronticornis, $S$. affinis and E. cornutum seems to be influenced by microclimatic factors. They were exclusively found in fruiting bodies sampled in a warm environment (exposed and south-west facing slopes with dry ground). O. festivus and its host, $S$. rugosum, were always found in moist and shady or semiexposed positions.

$R$. strandi was most common in fruiting bodies of $F$. fomentarius growing above ground (Mann-Whitney U test, $\mathrm{p}=0.00006$ ) in contrast to C. lineatocribratus and C. jacquemarti (Fig. 2). Pairwise tests gave significant differences between $R$. strandi and $C$. lineatocribratus $\left(\chi^{2}=45.78, \mathrm{df}=1\right.$, $\mathrm{p}<0.0001)$ and between $R$. strandi and $C$. jacquemarti $\left(\chi^{2}=83.93, \mathrm{df}=1, \mathrm{p}<0.0001\right)$. A significant difference was also evident when $C$. lineatocribratus vs. $C$. jacquemarti was tested pairwise $\left(\chi^{2}=9.25, \mathrm{df}=1, \mathrm{p}<0.0024\right)$. C. lineatocribratus was almost exclusively found in fruiting bodies sampled on ground (Mann-Whitney U test, $\mathrm{p}<$ 0.0000001 , see Fig. 2). C. jacquemarti was found abundant in fungi sampled in both heights, but a

Table 4. Mean number of cisids pr. 10 gram fungi found in fruiting bodies of Trametes spp., Fomes fomentarius, Phellinus spp., Piptoporus betulinus, Cerrena unicolor, Polyporus spp. and Stereum rugosum sampled in Balsfjord. Total number of cisids is given in brackets while the number of fungi in which they were found is given by the following number. Sampled fungi not considered in the table: Stereum $\operatorname{spp} .(N=7)$, Pycnoporus cinnabarinus $(\mathrm{N}=3)$, Oxyporus populinus $(\mathrm{N}=5)$, Pleurotus pulmonarius $(\mathrm{N}=7)$, Exidia spp. $(\mathrm{N}=1)$, Plicatura nivea $(\mathrm{N}=1)$, Chondrostereum purpureum $(\mathrm{N}=4)$, Inonotus obliquus $(\mathrm{N}=2)$, Bjerkandera adusta $(\mathrm{N}=4)$ and Tremella foliácea $(\mathrm{N}=1)$. For further explanation see Table 2.

\begin{tabular}{|c|c|c|c|c|c|c|c|}
\hline $\begin{array}{l}\text { Fungi name: } \\
\mathrm{N} \text { : } \\
\mathrm{n}: \\
\text { Fungi groups: }\end{array}$ & $\begin{array}{l}\text { Tram. } \\
31 \\
25 \\
(2)\end{array}$ & $\begin{array}{l}\text { F. fom, } \\
64 \\
43 \\
(9)\end{array}$ & $\begin{array}{c}\text { Phell. } \\
29 \\
4\end{array}$ & $\begin{array}{c}\text { P. bet. } \\
19 \\
4 \\
(3)\end{array}$ & $\begin{array}{l}\text { C. unic. } \\
15 \\
13 \\
(2)\end{array}$ & $\begin{array}{l}\text { Polyp. } \\
39 \\
2 \\
(1)\end{array}$ & $\begin{array}{c}\text { S. rug. } \\
19 \\
16\end{array}$ \\
\hline \multicolumn{8}{|l|}{ Cisidae } \\
\hline Cis bidentatus & 0.03 (1) 1 & $0.26(92) 9$ & $0.83(4) 3$ & $3.70(56) 4$ & $0.12(6) 2$ & $0.26(2) 2$ & $0.05(3) 2$ \\
\hline Cis jacquemarti & 0 & * $1.50(521) 21$ & 0 & 0 & 0 & 0 & 0 \\
\hline Cis lineatocribratus & $0.03(1) 1$ & * $1.06(372) 22$ & 0 & 0 & $0.02(1) 1$ & 0 & $\mathbf{0}$ \\
\hline Cis comptus & 0 & $\mathbf{0}$ & 0 & 0 & * $5.12(263) 13$ & 0 & 0 \\
\hline Cis boleti & * $18.40(583) 24$ & 0 & 0 & 0 & $0.06(3) 1$ & 0 & $\mathbf{0}$ \\
\hline Cis hispidus & * $5.86(186) 14$ & $\mathbf{0}$ & 0 & 0 & 0.06 (3) 1 & 0 & 0 \\
\hline Orthocis festivus & 0 & $\mathbf{0}$ & $<0.01(1) 1$ & $\mathbf{0}$ & 0 & 0 & * 3.06 (188) 16 \\
\hline Octotemnus glabriculus & * $1.30(41) 8$ & $\mathbf{0}$ & o & 0 & 0 & 0 & $\mathbf{0}$ \\
\hline Number of species & 5 & 3 & 2 & 1 & 5 & 1 & 2 \\
\hline Volume (cal.)• & - & 4585 & 5834 & 5068 & - & - & - \\
\hline Weight (g.) & 317 & 3492 & 1020 & 671 & 511 & 78 & 614 \\
\hline
\end{tabular}

$\mathrm{N}$ : total number of fungi sampled. For further explanation see Table 2. n: number of attacked fungi, $\bullet$ : Volume calculated $\left(\mathrm{cm}^{3}\right)$. 
significant (Mann-Whitney U test, $\mathrm{p}=0.04$ ) difference was found regarding height above ground (Fig. 2). Thus, C. lineatocribratus shows a stronger attraction for fruiting bodies on the ground than does $C$. jacquemarti (Fig. 2).

\section{Discussion}

Previous studies on fungi-species preferences of insects included the number of insect specimens per fruiting body (e.g. Økland 1995). This method gives equal values to each unit of fungi regardless of volume or weight, which differs within and between species. However, density measures of insect specimens by means of estimates of the size of each fruiting body are considered to be important in preference studies of fungivorous species.

Calculation of volume makes sense only when the fruiting bodies are pileate. Dry weight is applicable on all types of fruiting bodies. Vacuum packed fungi dipped in water (measure of volume) gives a precise measure of the volume at the same time as the technique can be used on all types of fruiting bodies, whether it is pileate, imbricate or resupinate. Since the results of the last two methods were highly correlated, both may be adequate in

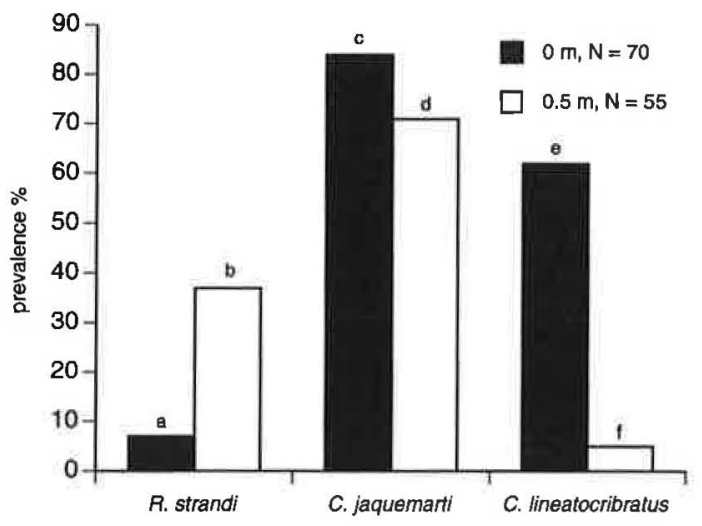

Fig. 2. Prevalence of cisids associated with Fomes fomentarius according to height above ground: $0 \mathrm{~m}=$ fruiting bodies sampled from logs on the ground; $0.5 \mathrm{~m}=$ fruiting bodies sampled from $0.5-2 \mathrm{~m}$ on standing trunks; $\mathrm{N}=$ number of fruiting bodies. The number of individuals pr. gram fruiting body were tested statistically. Significance in difference is given above each bar as small letters. Different letters within each species represent significant differences $(p<0.05)$ (MannWhitney U test). Pairwise comparison (Chi-square tests) revealed significant differences $(p<0.05)$ in prevalence between the three cisid species.

quantitative studies of fungivorous species.

The sporocarps sampled in field $1 \mathrm{~b}$ and $3 \mathrm{~b}$ are

Table 5. Mean number of cisids pr. 10 gram fungi found in fruiting bodies of Trametes spp., Phellinus spp., Piptoporus betulinus, Cerrena unicolor, Stereum rugosum, Pycnoporus cinnabarinus and Polyporus spp. sampled in Tromsø. Total number of cisids is given in brackets while the number of fungi in which they were found is given by the following number. Sampled fungi not considered in the table: Fomes fomentarius $(\mathrm{N}=2)$, Inonotus obliquus $(\mathrm{N}=1)$, Pleurotus pulmonarius $(\mathrm{N}=3)$ and Stereum spp. $(\mathrm{N}=7)$. For further explanation see Table 2.

\begin{tabular}{lccccccc}
\hline Fungi name: & Tram. & Phell. & P. bet. & C. unic. & S. rug. & P. cin. & Polyp. \\
$\mathrm{N}:$ & 56 & 54 & 5 & 13 & 33 & 14 & 11 \\
$\mathrm{n}:$ & 47 & 0 & 1 & 2 & 1 & 0 & 0 \\
Fungi group: & $(2)$ & & $(3)$ & $(2)$ & & (2) & $(1)$
\end{tabular}

\section{Cisidae}

Cis bidentatus
Cis boleti
Cis hispidus
Octotemnus glabriculus
Sulcacis affinis
Number of species
Volume (cal.)•
Weight (g.)

$\begin{array}{ccc}\mathbf{0} & \mathbf{0} & \mathbf{3 . 0 0}(51) 1 \\ \text { * } 28.16(2321) 46 & 0 & 0 \\ * \mathbf{5 . 8 7}(484) 18 & 0 & 0 \\ { }^{*} \mathbf{4 . 0 4}(333) 17 & 0 & 0 \\ \mathbf{0 . 2 3}(19) 3 & \mathbf{0} & \mathbf{0} \\ 4 & 0 & 1 \\ - & 15680 & - \\ 824 & 1401 & 169\end{array}$

$0.14(9) 2$
0
0
0
0
1
-
657

$\begin{array}{ccc}\mathbf{0 . 0 7}(5) 1 & \mathbf{0} & \mathbf{0} \\ \mathbf{0} & \mathbf{0} & \mathbf{0} \\ \mathbf{0} & \mathbf{0} & \mathbf{0} \\ \mathbf{0} & \mathbf{0} & \mathbf{0} \\ \mathbf{0} & \mathbf{0} & \mathbf{0} \\ 1 & 0 & 0 \\ - & 617 & - \\ 720 & 70 & 75\end{array}$

$\mathrm{N}$ : total number of fungi sampled. For further explanation see Table $2 . n$ : number of attacked fungi, $\bullet:$ Volume calculated $\left(\mathrm{cm}^{3}\right)$. 
in a more comparable stage than the rest of the material. Nevertheless, the results from Tables 2-5 are in agreement with the results from $1 \mathrm{~b}$ and $3 \mathrm{~b}$ (Tables 6 and 7).

Paviour-Smith (1960a), Matthewman \& Pielou (1971), Lawrence (1973), Thunes (1994) and $\varnothing \mathrm{kland}(1995)$, divided taxa of fungi in host preference groups in which cisids are found. PaviourSmith (1960a) proposed that the beetle species and the species of fungi should be separated into two mutually exclusive breeding groups.

Host selection and a classification of the different taxa of fungi in which each cisid species is found are summarized in Table 8 . A division of fungi into three "host preference groups" could be made: (i) the Trametes group, (ii) the Fomes and Daedalea group and (iii) the genus Stereum. Despite this grouping, most of the cisids tend to prefer single genera, and two species appear to be species-specific (O.festivus and $R$. strandi) (Table 8).

Taxonomically closely related cisid species tend to select the same taxa of fungi. Accordingly, C. lineatocribratus and $C$. jacquemarti are closely related and prefer $F$, fomentarius. C. boleti, C. hispidus and $C$. comptus are also closely related and select Trametes spp. or the closely related C. unicolor. The species of Orthocis probably prefer species of fungi other than Polyporaceae. This is evident for $O$. festivus (Table 8) and it is also likely for the two other species of the genus occuring in Troms: Orthocis alni (Gyll.) and Orthocis linearis (Sahlb.). Thus, O. alni is one of the most common cisid species found in window traps in Dividalen ( $\varnothing$. Huse, pers. comm.) indicating that it must be quite common. Nevertheless, we have not found it amongst the fungi species we have examined (Table 1), although Koch (1989) mentioned Exidia glandulosa and Stereum rugosum as hosts for $O$. alni. It remains to be found what types of fungi these two Orthocis species prefer.

Several factors seem to contribute to the fungus choice of cisid species: differences of the fruit-

Table 6. Mean number of cisids pr. $10 \mathrm{ml}$ fungi found in dead and/or attacked fruiting bodies of Trametes spp., Fomes fomentarius, Phellinus spp. and Piptoporus betulinus sampled in Dividalen (site 1b) between 12-23 September 1994. Sampled fungi without attack and $N \leq 7$ are not considered in the table: Cerrena unicolor $(N=2)$. Total number of cisids is given in brackets while the number of fungi in which they were found is given by the following number. Host preference for fungi species was tested with Mann-Whitney U Test for all cisid species pr. $\mathrm{ml}$ fungi exceeding ten individuals in at least one fungus species. Figures with asterics denote that the abundance is significantly higher than in all the other fungus species $(p<0.05)$.

\begin{tabular}{lcccc}
\hline Fungi name: & Tram. & F. fom. & Phell. & P. bet. \\
$\mathrm{N}:$ & 11 & 27 & 28 & 16 \\
$\mathrm{n}:$ & 11 & 24 & 1 & 0 \\
Fungi group: & $(2)$ & $(9)$ & & $(3)$
\end{tabular}

Cisidae

$\begin{array}{lc}\text { Cis bidentatus } & \mathbf{0 . 0 2}(1) 1 \\ \text { Cis jacquemarti } & \mathbf{0 . 0 2 ( 1 )} 1 \\ \text { Cis lineatocribratus } & 0 \\ \text { Cis boleti } & * 2.45(143) 9 \\ \text { Cis hispidus } & * 9.00(524) 9 \\ \text { Octotemnus glabriculus } & * 6.91(403) 7 \\ \text { Sulcacis affinis } & \mathbf{0 . 0 2 ( 1 ) 1} \\ \text { Ennearthron cornutum } & 0 \\ \text { Ropalodontus strandi } & 0 \\ \text { Number of species } & 6 \\ \text { Volume (cal.) } & - \\ \text { Volume (ms.) } & 583 \\ \text { Weight (g.) } & 129 \\ \text { \% sampled } f & 100\end{array}$

$0.01(8) 4$
$* 0.12(72) 13$
$0.04(22) 2$
0
0
0
0
$<0.01(3) 3$
$* 0.68(408) 18$
5
11208
6018
1540
50

50

$\begin{array}{cc}<0.01(1) 1 & 0 \\ 0 & 0 \\ 0 & 0 \\ 0 & 0 \\ 0 & 0 \\ 0 & 0 \\ 0 & 0 \\ 0 & 0 \\ 0 & 0 \\ 1 & 0 \\ 11177 & 3191 \\ 4939 & 1500 \\ 2657 & 663 \\ 50 & 100\end{array}$

$f: \%$ of total number of fungi in the investigated area. $\mathrm{N}$ : total number of fungi sampled. For further explanation see Table 2. $\mathrm{n}$ : number of attacked fungi, $\bullet$ : volume calculated $\left(\mathrm{cm}^{3}\right)$, $\downarrow$ : volume measured $(\mathrm{ml})$. 
ing bodies in the durational stability (Hanski 1989, Økland 1995), in hyphal structure (Paviour-Smith 1960a), or hardness (Klopfenstein \& Graves 1989, $\varnothing$ kland 1995), or differences in mouth morphology and feeding strategy between the cisid species (Lawrence 1989). The durational stability of most Polyporaceae is obviously sufficient to support many cisid species. Although Trametes spp. are annual, their fruiting bodies persist for a long time after death (2-3 years), and they harbour more cisid species than any other fungi taxa do (Table 8). Species of the Phellinus igniarius group may be too hard to be attacked by cisid species since hardly any of them use Phellinus spp. as hosts (Table 8, see also Økland 1995). However, despite that $F$. fomentarius is a comparatively hard species, it is used as a host by almost as many species as Trametes spp. According to our opinion, therefore, a hypothesis involving softness and durability of the host to explain species richness of insects in fungi is of limited applicability to cisids.

The fact that several cisids found in Trametes spp. have been extracted exclusively from soft bodied fungi (Trametes spp., C. unicolor and Trichaptum spp.), may indicate that their mandibles are adapted to chew relatively soft fungi. The species associated with hard fungi seem to have heavily developed mandibles adapted to chew such fungi (Entwhistle 1955, unpubl.). However, it is reasonable that the species adapted to chew woody fungi are able to chew softer fungi as well. Nevertheless, the species preferring $F$. fomentarius mostly occur as stragglers in soft bodied fungi (Tables 4, 6, 7 and 8).

It is likely that olfactory stimuli play a major role when cisids locate the host (Lawrence 1973), as it does for bark beetles (Wood \& Bushing 1963, Wood 1982). Paviour-Smith (1960a) argued that it seems very unlikely that the answer to the question about the choice of fungi will be found by the postulation of special chemical attractants or repellents in the fruiting bodies themselves. She suggested that a general odour from decaying wood could work as a stimulus to the cisid species. However, the specialized host preference shown by most of the cisids, indicates rather a response to volatiles from fungi than to a general odour of a decaying tree (see also Jonsell \& Nordlander (1995)). This is also in accordance with the following: the cisid species select fungus species across tree species. For example, several cisid

Table 7. Mean number of cisids pr. $10 \mathrm{ml}$ fungi found in dead and/or attacked fruiting bodies of Trametes spp., Fomes fomentarius, Phellinus spp., Stereum rugosum, sampled in Balsfjord September-October 1995. Sampled fungi without attack and $\mathrm{N} \leq 7$ are not considered in the table: Pleurotus pulmonarius $(\mathrm{N}=5)$ and Oxyporus populinus $(\mathrm{N}=1$ ). Total number of cisids is given in brackets while the number of fungi in which they were found is given by the following number. For further explanation see Table 6 .

\begin{tabular}{lcccc}
\hline Fungi name: & Tram. & F. fom. & Phell. & S. rug. \\
$\mathrm{N}:$ & 27 & 31 & 32 & 7 \\
$\mathrm{n}:$ & 27 & 24 & 1 & 7 \\
Fungi group: & $(2)$ & $(9)$ & &
\end{tabular}

\section{Cisidae}

\begin{tabular}{|c|c|c|c|c|}
\hline Cis bidentatus & 0 & 0 & $0.02(2) 1$ & ${ }^{*} 0.27(16) 4$ \\
\hline Cis jaquemarti & $0.04(4) 3$ & * 0.53 (407) 21 & $\mathbf{0}$ & 0 \\
\hline Cis lineatocribratus & $0.05(5) 4$ & * $1.63(1240) 20$ & $\mathbf{0}$ & $\mathbf{0}$ \\
\hline Cis boleti & * $4.38(420) 24$ & 0 & 0 & 0 \\
\hline Cis hispidus & * $2.48(238) 15$ & $\mathbf{0}$ & $\mathbf{0}$ & 0 \\
\hline Orthocis festivus & 0 & $\mathbf{0}$ & $\mathbf{0}$ & ${ }^{*} 0.73(43) 6$ \\
\hline Octotemnus glabriculus & * $3.02(290) 22$ & 0 & $\mathbf{0}$ & 0 \\
\hline Rhopalodontus strandi & 0 & $<0.01$ (1) 1 & $\mathbf{0}$ & 0 \\
\hline Number of species & 5 & 3 & 1 & 2 \\
\hline Volume (ms.) & 959 & 7615 & 1059 & 587 \\
\hline Weight (g.) & 148 & 2401 & 615 & 123 \\
\hline$\%$ sampled $f$ & 100 & 100 & 100 & 100 \\
\hline
\end{tabular}

$f: \%$ of total number of fungi in the investigated area. N: total number of fungi sampled. For further explanation see Table 2. n: number of attacked fungi, $\downarrow$ : volume measured $(\mathrm{ml})$. 
species (e.g. C. boleti, C. hispidus, O. glabriculus) prefer Trametes spp., but these fungi grow on a wide variety of deciduous trees (Betula, Alnus, Populus, Salix) whereas P. betulinus, which exclusively grows on Betula, is completely unattacked by the same cisid species. Furthermore, a fresh fruiting body probably emits stronger and more specific odours than older ones and decaying trees. Together with old, decomposed fruiting bodies, newly formed ones are usually found on the same site (stem, twig, stump). The reason for this is that the mycelium exists for many years inside the wood, producing fruiting bodies over several years. Cisids may therefore orientate to a new site using chemical cues emitted from fresh fruiting bodies although dead sporocarps within the site usually are used as breeding places.

Pheromones produced (perhaps in the feces) by the first colonizing specimens, which would attract other members of the species, may also play a role in host detection (Lawrence 1973).

The present results indicate that microclimatic factors have no crucial effect on the host selection of most of the cisids since they were usually found in the same fungi species irrespective of exposure and moisture. S. affinis, S. fronticornis and $E$. cornutum, however, occurred only in fungi associated with a warm and dry environment although their hosts, Trametes spp. and $F$. fomentarius, were sampled in all microclimatic categories.

The cisid species preferring $F$. fomentarius select sporocarps at different heights above ground (Fig. 2). R. strandi mostly colonizes fungi above ground whereas $C$. lineatocribratus is found almost exclusively in fungi sampled on the ground. C. jacquemarti occurred in fungi sampled from both heights, but it was found in significantly more fungi sampled on the ground than off the ground (Fig. 2). It is possible, therefore, that $R$. strandi colonizes the fungi before $C$. jacquemarti and the latter species before $C$. lineatocribratus. Another possibility is that $C$. lineatocribratus prefers wetter sporocarps than the other two cisid species, irrespective of their age or successional stage. Thus, sporocarps which have grown near the ground are usually wet, contrary to those present on standing trees (Paviour-Smith 1960a). One consequence of this division of the host may be that $C$. jacquemarti and especially C. lineatocribratus locate hosts when crawling on the ground. $C$. $l i$ -

Table 8. Utilization categories of cisids summarized according to associated fungi. Optimal host: the species feed and reproduce; Suboptimal host: the species feed and may reproduce, but have a lower density and prevalence than the former; Straggler: the species may feed, but no sign of reproduction; Zero: no individuals found. ? is added when the given category might be too high. Figures underlined indicate eclosion (1: larvae or pupae were found as adults in a later investigation of a sample or 2: teneral specimens).

\begin{tabular}{lccccc}
\hline Fungi species: & Pleurotus & Polyporus & Trametes & Cerrena & Trichaptum \\
& pulmonarius & spp. & spp. & unicolor & spp. \\
Fungi group: & $(1)$ & $(1)$ & (2) & (2) & (2)
\end{tabular}

\section{Cisidae}

Cis bidentatus

Cis jaquemarti

Cis lineatocribratus

Cis comptus

Cis boleti

Cis hispidus

Cis punctulatus

Orthocis festivus

Octotemnus glabriculus

Sulcacis fronticornis

Sulcacis affinis

Ennearthron cornutum

Ropalodontus strandi

$\begin{array}{cc}\text { zero } & \text { straggler } \\ \text { zero } & \text { zero } \\ \text { zero } & \text { zero } \\ \text { zero } & \text { zero } \\ \text { straggler } & \text { zero } \\ \text { straggler } & \text { straggler } \\ \text { zero } & \text { zero } \\ \text { zero } & \text { zero } \\ \text { zero } & \text { zero } \\ \text { zero } & \text { zero } \\ \text { zero } & \text { zero } \\ \text { zero } & \text { zero } \\ \text { zero } & \text { zero }\end{array}$

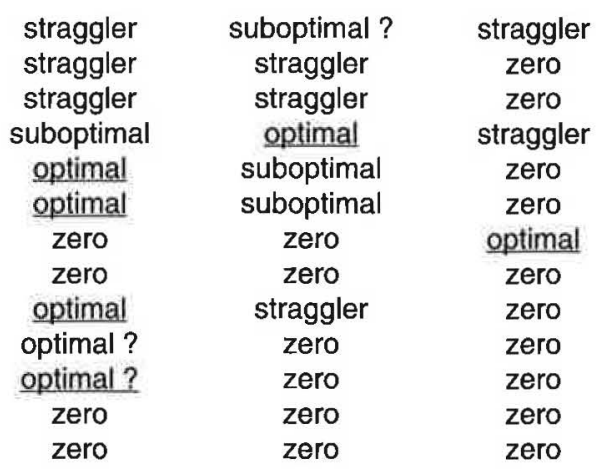


neatocribratus is frequently found in pitfall traps (Thunes 1994), supporting this hypothesis.

Contrary to $C$. lineatocribratus, $R$. strandi may mostly orientate in flight, prior to landing. Catches from traps designed by Kaila (1993) agree with the hypothesis that $R$. strandi prefers fruiting bodies growing above ground on standing trees (Olberg, unpublished data).

Tømmerås \& Mustaparta (1989), tested single cell responses to volatiles from host and nonhost species in the ambrosia beetle Trypodendron lineatum (Oliver). Their results suggested that odour cells respond to one or a few compounds and that minor constituents are rather important. Similar experiments ought to be conducted on cisids by using volatiles extracted from different polypore species to elucidate the host preference/ selection mechanisms in these species.

Acknowledgements. We would like to express our gratitude to A. C. Nilssen and Dr. A. Skorping for valuable discussions and criticism on earlier drafts of the manuscript. We also thank G. M. Jensen and L. Ryvarden for help in identifying the species of fungi and N. Peterson for help with the English.

\section{References}

Ackerman, J. K. \& Shenefeldt, R. D. 1973: Organisms, especially insects, associated with wood rotting higher fungi
(Basidiomycetes) in Wisconsin forests. - Trans. Wis. Acad. Sci. Arts. Lett. 61: 185-206.

Benick, L. 1952: Pilzkäfer und Käferpilze. - Acta. Zool. Fenn. 70: 1-250.

Crowson, R. A. 1981: The biology of the Coleoptera. Academic Press, London. 802 pp.

Eriksson, J., Hjortstam, K. \& Ryvarden, L. 1984: The Corticiaceae of North Europe. Vol. 7. - Universitetsforlaget, Oslo: 1282-1449.

Fjellberg, A. 1985: Norske Insekttabeller nr. 7. - Norsk Entomologisk Forening. 35 pp. (In Norwegian.).

Freude, H., Harde, K. W. \& Lohse, G. A. 1967: Die Käfer Mitteleuropas. Bd. 7. - Goecke \& Evers Verlag, Krefeld. 310 pp. (In German.).

Gilbertson, R. L. 1984: Relationships between insects and wood-rotting Basidiomycetes. - In: Wheeler, Q. \& Blackwell, M. (ed.), Fungus-insect relationships: 130165. Columbia University Press, New york.

Graves, R. C. 1960: Ecological observations on the insects and other inhabitants of woody shelf fungi (Basidiomycetes: Polyporaceae) in the Chicago area. - Ann. Entomol. Soc. Amer. 53: 61-78.

Hansen, V. 1951: Clavicomia 2 og Bostrychoidea. Danmarks fauna. - Gads forlag, København, Denmark. 253 pp. (In Danish.).

Hanski, I. 1989: Fungivory: Fungi, Insects and Ecology, In: Wilding, H. N., Collins, N. M., Hammond, P. M. \& Webber, J. F. (ed.), Insect-fungus interactions. - Academic Press, London: 25-68.

Jonsell, M. \& Nordlander, G. 1995: Field attraction of Coleoptera to odours of the wood-decaying polypores Fomitopsis pinicola and Fomes fomentarius, - Ann. Zool. Fennici 32: 391-402.

Kaila, L. 1993: A new method for collecting quantitative samples of insects associated with wood fungi. - En-

Table 8. Continued.

\begin{tabular}{lcccccc}
\hline Fungi species: & $\begin{array}{c}\text { Piptoporus } \\
\text { betulinus } \\
\text { Fungi group: }\end{array}$ & $\begin{array}{c}\text { Fomes } \\
\text { fomentarius } \\
(9)\end{array}$ & $\begin{array}{c}\text { Phellinus } \\
\text { spp. }\end{array}$ & $\begin{array}{c}\text { Stereum } \\
\text { hirsutum }\end{array}$ & $\begin{array}{c}\text { Stereum } \\
\text { rugosum }\end{array}$ & $\begin{array}{c}\text { Stereum san- } \\
\text { guinolentum }\end{array}$ \\
\hline Cisidae & & & & & & \\
Cis bidentatus & optimal & suboptimal ? & straggler & straggler & optimal ? & straggler \\
Cis jaquemarti & suboptimal & optimal & straggler & zero & zero & zero \\
Cis lineatocribratus & straggler & optimal & suboptimal ? & zero & straggler & straggler \\
Cis comptus & zero & zero & zero & zero & zero & straggler \\
Cis boleti & zero & zero & zero & zero & zero & zero \\
Cis hispidus & zero & straggler & zero & zero & zero & zero \\
Cis punctulatus & zero & zero & zero & zero & zero & zero \\
Orthocis festivus & zero & zero & straggler & straggler & optimal & zero \\
Octotemnus glabriculus & zero & zero & zero & zero & zero & zero \\
Sulcacis fronticornis & zero & zero & zero & zero & zero & zero \\
Sulcacis affinis & zero & zero & zero & zero & zero & zero \\
Ennearthron cornutum & zero & optimal ? & zero & zero & zero & zero \\
Ropalodontus strandi & zero & optimal & zero & zero & zero & zero \\
\hline
\end{tabular}


tomol. Fennica 4: 21-23.

Kaila, L., Martikainen, P., Punttila, P. \& Yakolev, E. 1994: Saproxylic beetles (Coleoptera) on dead birch trunks decayed by different Polypore species. - Ann. Zool. Fennici 31: 97-110.

Klimaszewski, J. \& Peck, S. B. 1986: Succession and phenology of beetle faunas (Coleoptera) in the fungus Polyporellus squamosus (Huds.: Fr.) Karst. (Polyporaceae) in Silesia, Poland. — Can. J. Zool. 65: 542-550.

Klopfenstein, P. C. \& Graves, R. C. 1989: Feeding preference and adult survival of Hadraule blaisdelli (Coleoptera: Cisidae) on different host fungi (Polyporaceae). —Ent. News, 100 (4): 157-164.

Koch, K. 1989: Die Käfer Mitteleuropas. Ökologie 2. Goecke \& Evers, Krefeld. 382 pp. (In German.).

Krasutskiy, B. V. 1996: Fungicolous Coleoptera of woodattacking Basidiomycetes in the taiga forests of West Siberia - Ent. Rev. 75: 67-77.

Lawrence, J. F. 1971: Revision of the North American Ciidae (Coleoptera). — Bull. Mus. Comp. Zool. 142:419522.

Lawrence, J. F. 1973: Host preference in ciid beetles (Coleoptera: Ciidae) inhabiting the fruiting bodies of Basidiomycetes in North America. - Bull. Mus. Comp. Zool., 145: 163-212.

Lawrence, J. F. 1989: Mycophagy in Coleoptera: Feeding strategies and morphological adaptions. In: Wilding, H.N., Hammond, P. M. and Webber, J. F. (ed.), Insect-fungus interactions. - Academic Press, London. 1-23.

Lundberg, S. 1995: Catalogus Coleopterorum Sueciae. Naturhistoriska Riksmuseet \& Entomologiska Föreningen i Stockholm, Stockholm.

Matthewman, W. G. \& Pielou, D. P. 1971: Arthropods inhabiting the sporophores of Fomes fomentarius (Polyporaceae) in Gatineau Park, Quebec. - Can. Entomol. 103: 775-847.

Midtgaard, F. 1996: The significance of fragmentation of boreal forest for the occurrence of selected Coleoptera. - Dr. Scient thesis, Department of Biology, University of Oslo. $146 \mathrm{pp}$.

$\varnothing \mathrm{kland}, \mathrm{B} .1995$ : Insect fauna compared between six polypore species in a southern Norwegian spruce forest. -
Fauna norv. Ser. B 42: 21-46.

Paviour-Smith, K. 1960a: The fruiting bodies of macrofungi as habitats for beetles of the family Cisidae (Coleoptera). — Oikos 11: 1-71.

Paviour-Smith, K. 1960b: Insect succession in the "birchbracket fungus" Polyporus betulinus. - Intern. Kongr. Ent. Wien, Verhand1. 1: 792-796.

Rothman, K. J. 1990: No adjustments are needed for multiple comparisons. - Epidemiology 1: 43-46.

Ryvarden, L. 1976: The Polyporaceae of North Europe. Volume 1. Fungiflora. - Universitetsforlaget. Oslo, Norway: $1-218$.

Ryvarden, L. 1978: The Polyporaceae of North Europe. Volume 2. Fungiflora, - Universitetsforlaget. Oslo, Norway: 219-507.

Ryvarden, L. 1991: Genera of Polypores. Nomenclatures and taxonomy. Synopsis Fungorum 5, Fungiflora. Grønlands Grafiske A/S Oslo, Norway: 1-362.

Ryvarden, L. \& Gilbertson, L. 1993: European Polypores. Part 1 and 2. Fungiflora. - Universitesforlaget. Oslo, Norway: 1-743.

Saalas, V. 1923: Die Fichtenkäfer Finnlands. - Ann. Acad. Scicnt. Fenn. A. 22: 1-746.

Sokal, R. R. \& Rohlf, F. J. 1981: Biometry. — Freeman, New York. 859 pp.

Thunes, K. H. 1994: The coleopteran fauna of Piptoporus betulinus and Fomes fomentarius (Aphyllophorales: Polyporaceae) in northem Norway. - Entomol. Fennica 5: $157-168$.

Tømmerås, B. Å. \& Mustaparta, H. 1989: Single cell responses to pheromones, host and non-host volatiles in the ambrosia beetle Trypodendron lineatum. - Entomol. exp. appl. 52: 141-148.

Wood, D. L. 1982: The role of pheromones, kairomones, and allomones in the host selection and colonization behavior of bark beetles. - Ann. Rev. Entomol. 27: 411-446.

Wood, D. L. \& Bushing, R. 1963: The olfactory response of Ips confusus (LeConte) (Coleoptera: Scolytidae) to the secondary attraction in the laboratory. - Can. Ent. 95: 1066-1078. 